\title{
Incomplete Freund's Adjuvant
}

National Cancer Institute

\section{Source}

National Cancer Institute. Incomplete Freund's Adjuvant. NCI Thesaurus. Code C1573.

A water-in-oil emulsion that stimulates the T-cell immune response to antigens and may be used in various types of cancer vaccines. ( $\mathrm{NCIO4}$ 